\title{
Interpretation of Dune Genesis from Sedimentogical Data and Ground Penetrating Radar (GPR) Signatures: A Case Study from Ashirmata Dune Field, Mandvi Beach, Gujarat, India
}

\author{
Deshraj Trivedi $^{1}$, Koravangatt Devi ${ }^{2}$, Ilya Buynevich ${ }^{3}$, P. Srinivasan ${ }^{4}$, K. Ravisankar ${ }^{4}$, Vipul Silwal ${ }^{1}$, \\ D. Sengupta ${ }^{1}$, Rajesh R. Nair ${ }^{2}$ \\ ${ }^{1}$ Department of Geology and Geophysics, Indian Institute of Technology, Kharagpur, India \\ ${ }^{2}$ Department of Ocean Engineering, Indian Institute of Technology, Chennai, India \\ ${ }^{3}$ Department of Earth and Environmental Science, Temple University, Philadelphia, USA \\ ${ }^{4}$ Structural Engineering Research Centre, Chennai, India \\ Email: rajeshnair@iitm.ac.in
}

Received February 10, 2012; revised March 15, 2012; accepted March 27, 2012

\begin{abstract}
The coastal dunes located near the Ashirmata region, south of Mandvi beach lies near the straight coast have been studied by making use of sedimentological information and Ground Penetrating Radar (GPR) data. Sedimentological analysis reveals the NNW-SSE trending longitudinal dunes consists of well sorted fine sands with unimodal distribution possibly formed by constant wind gust and also the point out to the origin of sediments from single source; mostly the sediments derived from Indus delta transported to beach by long shore drift and tidal waves, carried inland by local onshore winds. The radargram confirms, the homogenous sand layers with paleosols at shallow depth slip faces are probably formed due to extreme storm activity of Recent.
\end{abstract}

Keywords: Coastal Dune; Ashirmata Region; Sedimentogical Analysis; Ground Penetrating Radar; Paleosol

\section{Introduction}

Coastal dunes are mostly aeolian landforms develop in ocean-land interface has been active with adequate supply of loose sand-sized sediments transported to inlands by prevailing onshore wind or sea breeze. Coastal dunes are primarily the gradual product of wind rather than waves, which subtly changes the beach morphology with each passage; however major storms erode both $[1,2]$. The shape and orientation of the dune helps to determine the airflow and it further influences the transport of sands and the formation, and evolution of coastal dunes decide the airflow over it. The prime requirements for the formation of dunes are the supply of adequate sand and sufficient wind that can transport the sand particles and these sand particles should not be cohesive and cemented [3]. The dune type depends on sand availability and directional inconsistency of the prevailing wind pattern e.g., [4] longitudinal dunes are aligned parallel to each other and wind blowing parallel to the dune orientation with high sand availability. The size of the dune depends largely on the supply of sand sized sediments [5]. The prime factors depends on the dune stability are attack by wave and storms also continuous attack of the waves on dune base causes easy removal of sand by both offshore and along shore [5]. The rates of migration of dunes vary considerably over the year [6,7].

Many studies have done by researchers regarding the grain distribution studies along coastal dune sands [8-11]. Nordstrom [12] suggest that sediment sorting may be more significant than grain size in aeolian transport. Coastal dunes sediments are derived from aeolian activity are typically well sorted with mean grain size of 2 to $3 \phi$ [11]. The textural analyses and grain size distribution parameters were estimated for the study area by collecting representative samples from top and bottom layers of the dunes by disputing coastal dunes from the windblown sediments.

During the last few decades, Ground Penetrating Radar (GPR) has been used with great success on dunes investigation [13-19] and the GPR signatures revealed the internal stratigraphy and sedimentary structure of dunes by subsurface imaging and found to quite useful. GPR method is predominantly well suited to use in dry, sandy, or cobble-poor sediments [e.g., 13-19]. The depth 
of penetration of the radar signals decreases with the use of high frequency antenna as the produced signal undergoes less attenuation and high-quality signals as compared to low frequency antenna [13]. GPR allows rapid imaging of dune stratigraphy and provides information about lateral accretion surfaces, paleosol horizons, and thickness of units and relative chronology of dunes deposition, migration and deflation. Paleosols showing high amplitude response in GPR data is the result of their thickness and lithological contrast with surrounding aeolian sands [20,21]. This horizons indicate a period of soil development during a hiatus in dune activity, often in Eolianite (fossil dune limestone) [22]. But in the study area paleosols represents an erosional surface; occurs at shallow depth and the dune slip faces may be related to extreme storm activity, which are frequent in Gujarat coast. The most recent aeolian activity started the period in between $\sim 0.6 \mathrm{ka}$ to $\sim 0.2 \mathrm{ka}$ experienced decreased rainfall [23].

Our study is aimed to interpret basic geological driving force for the dune formation from sedimentology and also from GPR data by constructing the internal stratigraphy of the dunes.

\section{Study Area and Geological Settings}

The study area, Ashirmata dune fields $\left(22^{\circ} 50.230^{\prime} \mathrm{N}\right.$, $69^{\circ} 13.057^{\prime} \mathrm{E}$ and $\left.22^{\circ} 50.246^{\prime} \mathrm{N}, 69^{\circ} 13.062^{\prime} \mathrm{E}\right)$ lies north of Mandvi beach in Kutch coast, northern flank of the Gulf of Kutch (Figure 1).

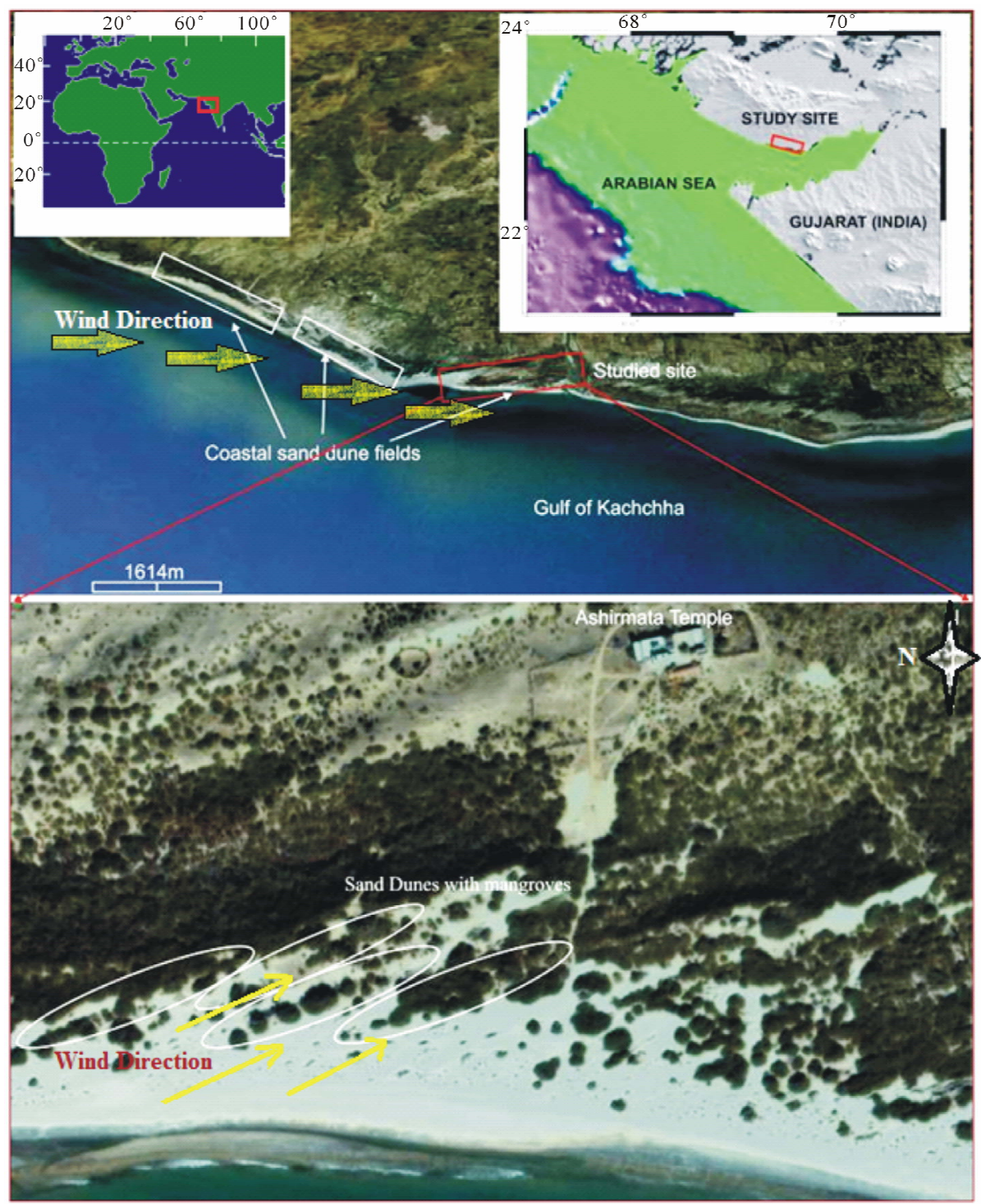

Figure 1. Location map of study site in Ashirmata dune fields near Mandvi beach in Gujarat. Yellow arrows indicates NW direction of wind pattern and circles and rectangles denotes the dune fields in the study area and nearby areas, mangrove vegetations are seen associated with these dunes. 
The North West part of the Gujarat, southern border of Thar Desert is extremely arid in case the location of the state near to Tropic of Cancer. The complex Cenozoic tectonic processes and associated sea level changes impart the coastal area results the present geological and geomorphological set up. Gujarat is largely underline by the flat alluvial fans, originated from structurally controlled rivers of eastern highlands of Deccan Trap and flowing through the tectonic slopes towards the Arabian Sea. The coast line of Kutch comprises Quaternary and Tertiary sediments which are mainly comprises friable sandstone, sand and silty sand along with tidal clay [24]. In the study area, the orientations of longitudinal dunes are generally along NNW to SSE direction, parallel to the prevailing winds and occur in the form of parallel or sub-parallel to the coast. Almost straight sand ridges with partial vegetation cover (Figures 2(A) and (B)), backed by sand hills with mangrove swamps and fronted by sand banks are characteristic of the study in dry season.

\section{Methodology}

The study area lies under the geographical coordinates $22^{\circ} 50.230^{\prime} \mathrm{N}, 69^{\circ} 13.057^{\prime} \mathrm{E}$ and $22^{\circ} 50.246^{\prime} \mathrm{N}, 69^{\circ} 13.062^{\prime} \mathrm{E}$, as acquired from the Global Positioning System (GPS). Sand samples were collected from three pits which are excavated in three dunes (D1, D2 and D3) (Figure 3) (after the primary investigation of GPR data, ground truthing have done for cross checking) and representative samples were collected from top and bottom of each pits, those samples were subjected to sedimentological analysis by using Malvern particle size analyzer. The statistical parameters such as mean, median, standard deviation, skewness and kurtosis were estimated by using standard statistical techniques for studying the textural characteristics (Table 1).

The GPR data collected by using Subsurface Interface Radar (SIR) 3000 system mode developed by Geophysical Survey System, Inc. (GSSI) with shielded monostatic
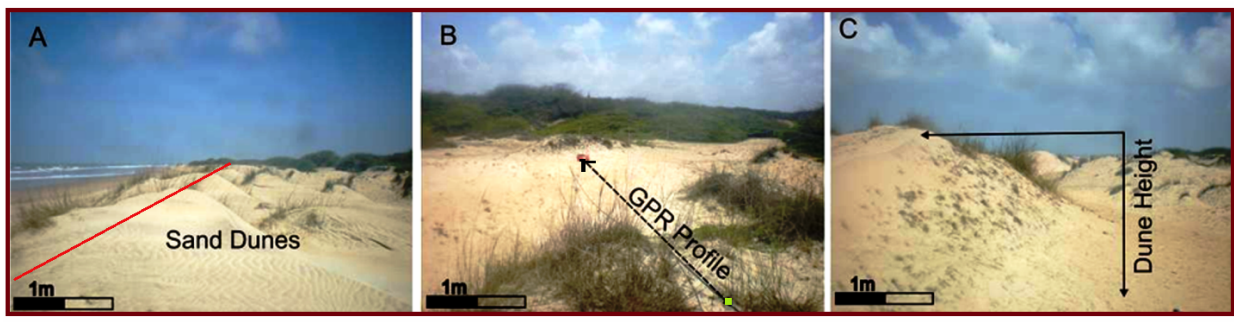

Figure 2. (A) Shows the orientation of sand dune fields (red line) sub parallel to the coast; (B) Demonstrates the transection of GPR profile from coast to land indicated by dotted arrow means the direction of data collection; (C) Denotes the schematic presentation of dune height, distance from top to base of the dune indicated by solid arrow line.

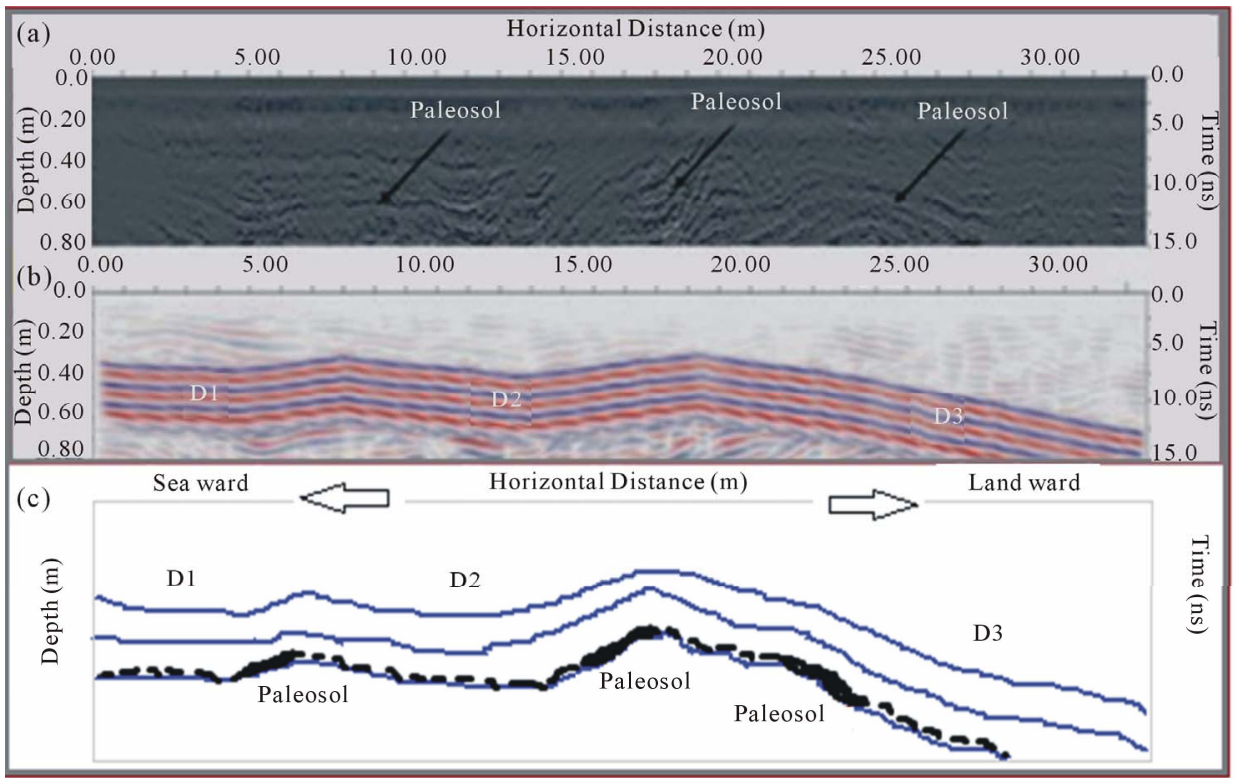

Figure 3. GPR signatures have shown in grey scale (a) and colour (b) images, paleosols can be clearly visible in (a) and dune morphology can be seen in (b). The schematic representation of GPR image, (c) showing the three dunes with continuous, homogenous sand layer and interapolation of paleosol layer. 
Table 1. Grain size distribution parameters shows textural group and sediment type of three dunes, samples were collected from top and bottom of each dunes (Mean-x, Sorting- $\sigma$, Skewness-Sk and Kurtosis-K).

\begin{tabular}{cccccc}
\hline Samples & $\mathrm{x}$ & $\sigma$ & $\mathrm{Sk}$ & $\mathrm{K}$ & Sample description \\
\hline D1 (Top) & 2.949 & 0.454 & 0.110 & 0.936 & Fine sand, well sorted, symmetrical, unimodal \\
D1 (Bottom) & 2.636 & 0.460 & 0.006 & 0.935 & Fine sand, well sorted, symmetrical, unimodal \\
D2 (Top) & 2.934 & 0.451 & 0.005 & 0.937 & Fine sand, well sorted, symmetrical, unimodal \\
D2 (Bottom) & 2.652 & 0.481 & -0.016 & 0.947 & Fine sand, well sorted, symmetrical, unimodal \\
D3 (Top) & 2.883 & 0.410 & 0.003 & 0.948 & Fine sand, well sorted, symmetrical, unimodal \\
D3 (Bottom) & 2.658 & 0.464 & 0.003 & 0.936 & Fine sand, well sorted, symmetrical, unimodal \\
\hline
\end{tabular}

antenna of $900 \mathrm{MHz}$ center frequency of maximum signal penetration was about $15 \mathrm{~ns}(0.80 \mathrm{~m})$. Several continuous profiles were collected along three dunes of $30 \mathrm{~m}$ length, NNW-SSE profile and the topographic survey was carried out using a Global Positioning System. The Radan 6.5 software is used to process the data and to correct the topography; the radargram undergoes basic and advanced processing such as surface normalization, filtering and migration.

\section{Results and Discussion}

\subsection{Morphology of the Dunes}

The interpretation from satellite imagery indicates that dune fields are distributed along the coastal plain, oblique to the present straight coast with mangrove vegetations growing associated with dunes and their density ceases towards land (Figure 1, Figure 2(A)). Dunes are oriented NNW to SSE and with increasing height towards land; dune 1 (D1) has $0.45 \mathrm{~m}$, dune 2 (D2) and dune 3 (D3) have $0.65 \mathrm{~m}$ and $1.3 \mathrm{~m}$ heights respectively (Figure 4, Figure 2(C)); in Ashirmata temple region height of the sand hill is approximately $30 \mathrm{~m}$. Figure 4 demonstrates the bar diagram showing distance versus dune height, signifies the gradual increase in dune height from sea to landward. The vigorously growing vegetation increases the residence time of deposited sediments in the dunes and act as shelter to prevent erosion [25], may be the reason of increase in dune height towards land. The lee and stoss angles generally increases from coast to land, such as leeward angle varies from $11.07^{\circ}$ in D1, $22.11^{\circ}$ in D2 and $15.78^{\circ}$ in D3 whereas the stoss angle varies from $7.76^{\circ}, 11.30^{\circ}$ and $13.30^{\circ}$ respectively (Table 2). The gentle slopes on both windward and leeward side mostly by deposition by wind rather than erosion. The morphology of the dunes and paleosols dipping direction indicates the wind direction, probably from NW to SE and the fine grained sediments of the dune formation may be transported by the strong E-W currents. Distinct ripple marks, shifting continuously, are found associated with the sand dunes. The Indus delta is composed of
Quaternary and Holocene sediments and during south west monsoon, sediments in sea water receding to inlands through the creeks and the deltaic sediments accumulated along the coastal area. The long shore currents and tides transported these sediments towards Gulf of Kutch region [26]. Tidal currents and local winds carried the grains onto the beach and landwards like the Colorado River delta sediments carrying sediments to El Pinacate dune fields [27]. The coastal segment between

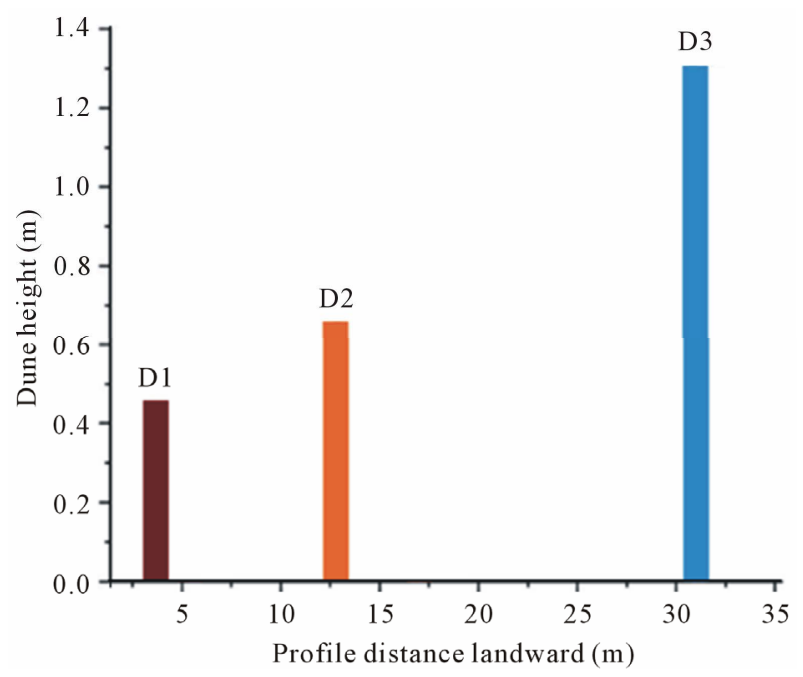

Figure 4. Bar diagram of dune height versus dune distance, dune height shows a gradual increase towards land. Dune 1 indicated by dark red with $0.35 \mathrm{~m}$ height, Dune 2 has 0.65 $\mathrm{m}$ and Dune 3 has $1.35 \mathrm{~m}$ heights, indicates by orange and blue respectively.

Table 2. Lee and stoss angles of the three dunes (D1, D2 and D3) along the GPR profile, estimated from GPR signature.

\begin{tabular}{cccc}
\hline Dune & $\begin{array}{c}\text { Dune height } \\
(\mathrm{m})\end{array}$ & $\begin{array}{c}\text { Stoss angle } \\
\text { (in degrees) }\end{array}$ & $\begin{array}{c}\text { Leeangle } \\
\text { (in degrees) }\end{array}$ \\
\hline Dune 1 & 0.45 & 7.76 & 11.07 \\
Dune 2 & 0.65 & 11.30 & 22.11 \\
Dune 3 & 1.3 & 13.3 & 15.78 \\
\hline
\end{tabular}


Jakhau and Mandvi constitute sediments with terrestrial composition, which are reworked and redistributed by littoral drift, onshore winds and cyclonic events [28].

The vegetation-free backshore act as an important role for the sediment supply and dune formation [29,30]; the higher the longshore accumulation of sand the higher will be the growth of the foredune and more sediments will be transported towards inland causes a non vegetative backshore [31]. Mostly vegetation stabilizes the dunes but in some conditions vegetated dunes may eroded and mobilized, and they act as a nucleus for the accumulation of aeolian sediments and give a larger area of stability, under suitable conditions small dunes join together and form a continuous dune ridge system [5]. The mangrove vegetation associated with the dunes far from coast shows increase in height than dunes nearby coasts, illustrate the dune stability in relation to the vegetation.

\subsection{Grain Size Analysis Interpretation}

The grain size analysis results mean grain size varies from $2.636 \phi$ to $2.949 \phi$ in phi scale falls under fine sand category, there is no much variation in grain size of top and bottom sediments indicate the same source of origin.
The sorting varies from 0.410 to 0.481 implies well sorted sand, mostly originated from windblown sediments, the general trend shows that bottom sediments are more sorted than top. The grain sorting usually improves with decrease in grain size $[32,33]$. The better sorted and fine-grained dune sands are the results of longer aeolian transport [34,35]. The skewness values in between -0.016 to 0.110 indicate symmetrically skewed unimodal grain distribution evidenced by single source origin of sediments and kurtosis varies from 0.948 to 0.935 represents mesokurtic nature [36] (Table 1). Compared to top layers, the fine and medium sand proportion is higher in bottom layer, and on the top of dune1 and dune 2, negligible amount of silt is found along with the sand (Figure 5). The percentage of medium sand is insignificant compared to the fine sand.

The particle size analysis of older dunes crests in Jaisalmer area perceived that coarser sand seen at top of the units indicated stabilized part of the crest due to the slow creeping of coarser sand for an extend period of time and finer sands generally seen on the mobile part [32,37,38]. Dunes of present study area is devoid of coarse grained sediments hence it is mostly younger dune complex and finer grain size implies the mobility of the dune to the

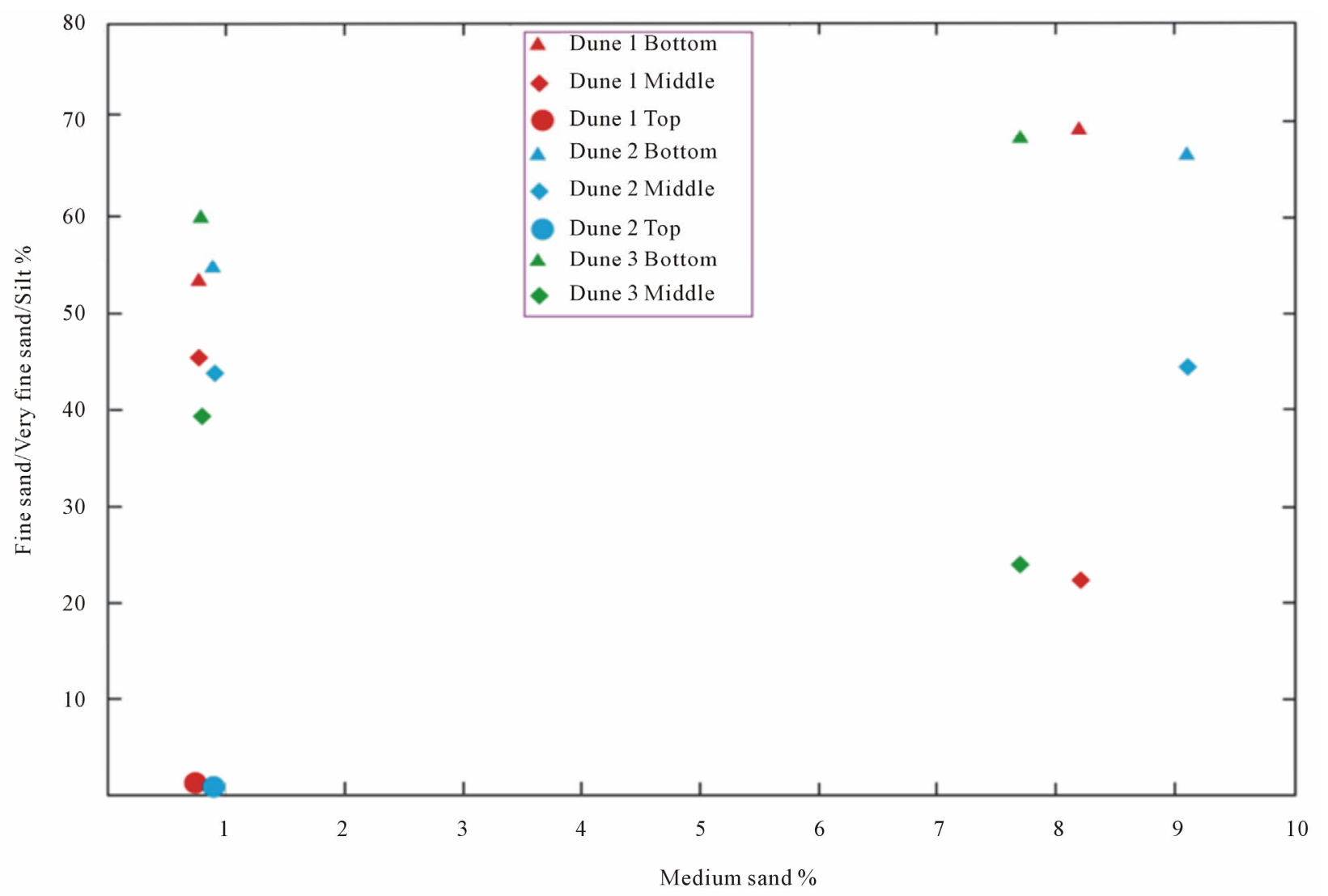

Figure 5. Plot showing the total fine, very fine sand and very coarse silt content of transverse dune types of Ashirmata Region Mandvi. 
prevailing wind direction. The mean grain size of older dunes has finer and better sorting than the dunes with reactivated crest and has a large difference in grain size and sorting [29].

\subsection{GPR Interpretation}

The resolution of the radargrams is sufficient for the identification of sedimentary structures and stratigraphic markers within the dune structure. The depth of penetration limited to $0.8 \mathrm{~m}$ prevents the detailed analysis of the dunes, but continues, homogeneous sand layers with dune 1 (D1), dune 2 (D2) and part of dune 3 (D3) can be observed with high resolution (Figure 3(a)). Paleosols are noticeable along the dune slip faces characterizes the erosional and/or depositional surface (Figure 3(b)), might be formed by extreme storm activity, which are common along Gujarat coast. Buynevich [39] described the paleosols formation in dune slip faces and associated heavy mineral concentrations are clearly recognized in high amplitude GPR reflections. The extend and thickness of the paleosols have long been used as the indicators of dune stability in coastal dune fields [40-46]. The undisturbed planar bedding planes are better preserved at shallow depth may be signifies the recent aeolian origin of sand deposits. The uniform thickness of sand layers indicates a continuous wind at constant rate and direction with steady supply of fine sand. [47,48] reported plains of north Gujarat evidenced by reddened paleosol related to aeolian deposits indicated pedogenesis and the formation of paleosol was strong in Gujarat plains [49,50]. In Thar Desert, Punjab and Haryana plains, weakly developed paleosol horizon noticed in near surface sediments of the dunes [51,52]. The paleosols in ancient dunes of Geelbek in the Western Cape of South Africa have the age of Late Pleistocene and Holocene related to the last glacial maximum [22].

Patel and Desai [53] attributed that strong aeolian activity and dune formation in Northern part of Gujarat related to regression pursuing the Flandrian sea level rise. The evidences from aeolian sediments implied that arid condition in Gujarat mainland prevailed up to at least 10 ka [54]. In northern Great Plains lakes, several periods of paleosol formation took place about 2300 - 2000, 1400 1000 and 600 - 500 cal years B.P. and aeolian activities occurred between these periods, may correspond to droughts [55]. According to Shukla [24] the coastal dunes and sand beaches in between Jhakau to Modwa segment (study area falls under this coastal region) is the result of waves, currents and tide dominated processes. These processes may continuously or intermittently influenced by the deposition of sands along the coastal regions, onshore wind promoted the accumulation of sand near to an obstacle and consequently dune results.
Thus, the dune formation of present study, point out Recent origin of the dunes by aeolian activity.

\section{Conclusion}

The present study utilized GPR signatures and statistical data from sedimentological analysis to determine the internal structure of the dunes and their formation. The conclusions from the present work indicates that the dunes are NNW-SSE oriented and non parallel to the coast is aligned parallel to the prevailing NW-SE wind direction and there is a general trend of increase dune height towards landward side. The origin of sediments may be from Indus deltaic sediments; transported and deposited to southward by long shore currents and tides. Winds carried these sediments to inland for further deposition. The sedimentological analysis results in fine grained, well sorted, unimodal sand derived from windblown sediments of single source of origin formed during Recent Age. The undisturbed, homogenous sand layers in the GPR signature symbolizes a constant, unidirectional wind that may resulted the dunes. Paleosols noticed in the shallow depth of GPR profile indicates that the erosional or depositional surface may be formed by extreme storm action, frequent in Gujarat coast.

\section{Acknowledgements}

Research work on the studied site was commenced through the financial assistance of Department of Science and Technology, New Delhi and Indian National Centre for Ocean Information Services, Hyderabad.

\section{REFERENCES}

[1] W. Ritchie and S. Penland, "Aeolian Sand Bodies of the South Lousiana Coast," Coastal Morphology and Research, John Wiley, Chichester, 1990, pp. 105-127.

[2] A. McLachlan, "Dissipative Beaches and Macrofauna Communities on Exposed Intertidal Sands," Journal of Coastal Research, Vol. 6, 1990, pp. 57-71.

[3] R. A. Bagnold, "The Physics of Blown Sand and Desert Dunes London: Methuen," Progress in Physical Geography, Vol. 18, No. 1, 1994, pp. 91-96. doi: $10.1177 / 030913339401800105$

[4] I. Livingstone and A. Warren, "Aeolian Geomorphology: An Introduction,” Longman, Essex, 1996, p. 221.

[5] R. A. Davis Jr. and D. M. FitzGerald, "Beaches and Coasts," Blackwell Science Ltd., Oxford, 2004, p. 419.

[6] J. A. Jimenez, L. P. Maia, J. Serra and J. Morais, “Aeolian Dune Migration along the Ceara Coat, North-Eastern Brazil," Sedimentology, Vol. 46, 1999, pp. 689-701. doi:10.1046/j.1365-3091.1999.00240.x

[7] N. Levin, H. Tsoar, H. J. Herrmann, V. Claudino-Sales and L. P. Maia, "Modelling the Formation of Arcuate Vegetated Dune Ridges Behind Barchans Dunes in NE 
Brazil," Sedimentology, Vol. 56, 2009, pp. 1623-1641. doi:10.1111/j.1365-3091.2009.01048.x

[8] B. Greenwood, "Spatial Variability of Texture over a Beach-Dune Complex, North Devon," Sedimentary Geology, Vol. 21, No. 1, 1978, pp. 21-44. doi:10.1016/0037-0738(78)90032-5

[9] K. Pye, "Morphological Development of Coastal Dunes in Humid Tropical Environment, Cape Bedford and Cape Flattery, North Queensland," Geographiska Annaler, Vol. A64, 1982, pp. 212-227.

[10] Vincent, "Differentiation of Modern Beach and Coastal Dune Sands-A Logistic Regression Approach Using the Parameters of the Hyperbolic Function," Sedimentary Geology, Vol. 49, No. 3-4, 1986, pp. 167-176. doi:10.1016/0037-0738(86)90036-9

[11] D. M. McCann, P. D. Jackson and P. J. Fenning, "Comparison of the Seismic and Ground Probing Radar Methods in Geological Surveying," Proceedings of the Institute of Electrical Engineers, Vol. 135, No. 4, 1988, pp. 380-390.

[12] K. F. Nordstrom, N. Psuty and R. W. G. Carter, "Coastal Dunes form and Process," Wiley, Chichester, 1986, p. 392.

[13] J. L. Davis and A. P. Annan, "Ground-Penetrating Radar for High Resolution Mapping of Soil and Rock Stratigraphy," Geophysical Prospecting, Vol. 37, No. 5, 1989, pp. 531-551. doi:10.1111/j.1365-2478.1989.tb02221.x

[14] R. L. Gawthorpe, R. E. L. Collier, J. Alexander, J. S. Bridges and M. R. Leeder, "Ground Penetrating Radar: Application to Sand Body Geometry and Heterogeneity Studies," In: C. P. North and D. J. Prosser, Eds., 14 Characterization of Fluvial and Aeloian Reservoirs, Geological Society Special Publication No. 73, The Geological Society, London, 1993, pp. 421-432.

[15] D. G. Smith and H. M. Jol, "Ground Penetrating Radar: Antenna Frequencies and Maximum Probable Depths of Penetration in Quaternary Sediments," Journal of Applied Geophysics, Vol. 33, No. 1, 1995, pp. 93-100.

[16] A. K. Benson, "Application of Ground Penetrating Radar in Assessing Some Geological Hazards: Examples of Groundwater Contamination, Faults, Cavities," Journal of Applied Geophysics, Vol. 33, No. 1-3, 1995, pp. 177-193.

[17] Z. Harari, "Ground-Penetrating Radar (GPR) for Imaging Strtigraphic Features and Groundwater in Sand Dunes," Journal of Applied Geophysics, Vol. 36, No. 1, 1996, pp. 43-52. doi:10.1016/S0926-9851(96)00031-6

[18] C. Bristow, J. Pugh and T. Goodall, "Internal Structure of Aeolian Dunes in Abu Dhabi Determined Using GroundPenetrating Radar," Sedimentology, Vol. 43, No. 6, 1996, pp. 995-1003. doi:10.1111/j.1365-3091.1996.tb01515.x

[19] J. J. Daniels, J. Brower and F. Baumgartner, "HighResolution GPR at Brookhaven National Laboratory to Delineate Complex Subsurface Targets," Journal of Environmental and Engineering Geophysics, Vol. 3, No. 1, 1998, pp. 1-6. doi:10.4133/JEEG3.1.1

[20] R. L. van Dam, E. H. Van Den Berg, S. Van Heteren, C. Kasse, J. A. M. Kenter and K. Groen, "Influence of Organic Matter on Radar-Wave Reflection: Sedimentologi- cal Implications," Journal of Sedimentary Research, Vol. 72, No. 3, 2002, pp. 341-352. doi:10.1306/092401720341

[21] G. A. Botha, C. S. Bristow, N. Porat, G. Dulle, S. J. Armitage, H. M. Roberts, B. M. Clarke, M. W. Kota and P. Schoeman, "Evidence for Dune Reactivation from GPR Profiles on the Maputuland Coastal Plain, South Africa, in Ground Penetrating Radar in Sediments," In: C. S. Bristow and H. M. Jol, Eds., Geological Society Special Publication, Vol. 211, 2003, pp. 29-46.

[22] P. Felix-Henningsen, A. W. Kandel and N. J. Conard, "The Significance of Calcretes and Paleosols on Ancient Dunes of the Western Cape South Africa, as Stratigraphic Markers and Paleoenvironmental Indicators," In: G. Füleky, Ed., Papers of the 1st International Conference on Archaeology and Soils, British Archaeological Reports. International Series, Vol. 1163, 2003, pp. 45-52.

[23] A. K. Singhvi and A. Kar, "The Aeolian Sedimentation Record of the Thar Desert," Proceedings of the Indian Academy of Science (Earth Planet Sciences), Vol. 113, No. 3, 2004, pp. 371-401.

[24] S. B. Shukla, S. P. Prizomwala, V. Ukey, N. Batt and L. S. Chamyal, "Coastal Geomorphology and Tsunami Hazard Scenario along Kuchchh Coat, Western India," Indian Journal of Geo-Marine Sciences, Vol. 39, 2010, pp. 549556.

[25] B. Carter and P. Wilson, "Geomorphological, Sedimentological and Pedological Influences on Coastal Dune Development in Ireland," Journal of Coastal Research, Special Issue, 1988, pp. 27-31.

[26] V. Ramaswamy, N. B. Nagender, P. Vethamony and D. Illangovan, "Source and Dispersal of Suspended Sediment in Macro-Tidal Gulf of Kuchchh," Marine Pollution Bulletin, Vol. 54, 2007, pp. 708-719. doi:10.1016/j.marpolbul.2007.01.026

[27] J. J. Kasper-Zubillaga and A. Carranza-Edwards, "Grain Size Discrimination between Sands of Desert and Coastal Dunes from Northwestern Mexico," Revista Mexicana de Ciencias Geologicas, Vol. 22, 2005, pp. 383-390.

[28] S. P. Prizomwala, S. B. Shukla and N. Bhatt, "Geomorphic Assemblage of the Gulf of Kachchh Coast, Western India: Implications in Understanding the Pathways of Coastal Sediments," Zeitschrift für Geomorphologie, Vol. 54, 2010, pp. 31-46. doi:10.1127/0372-8854/2010/0054-0003

[29] R. G. D. Davidson-Arnott and N. M. Pyskir, "Morphology and Formation of an Holocene Coastal Dune Field, Bruce Peninsula, Ontario," Géographie Physique et Quaternaire, Vol. 42, No. 2, 1988, pp. 163-170. doi:10.7202/032722ar

[30] K. Nordstrom, N. Psuty and B. Carter, Eds., "Coastal Dunes: Form and Process," Wiley, Chichester, 1988, p. 392.

[31] C. M. Marco, de M. Luna, E. J. R. Parteli, O. Durán and H. J. Herrmann, "Model for the Genesis of Coastal Dune Fields with Vegetation," Geomorphology, Vol. 129, 2011, pp. 215-224. doi:10.1016/j.geomorph.2011.01.024

[32] A. Kar, "Morphology and Evolution of Sand Dunes in the Thar Desert as Key to Sand Control Measures," Indian 
Journal of Geomorphology, Vol. 1, No. 2, 1996, pp. 177206.

[33] S. K. Wadhawan, "Textural Attribute of Recent Aeolian Stratigraphy in the Ghaggar Basin of Thar Desert, India," Journal of Arid Environments, Vol. 32, 1996, pp. 59-74. doi:10.1006/jare.1996.0006

[34] M. R. Leeder,“ Sedimentology: Process and Product”, Allen and Unwin, London, 1982, p. 344.

[35] J. J. Kasper-Zubillaga and A. Carranza-Edwards, "Grain Size Discrimination between Sands of Desert and Coastal Dunes from Northwestern Mexico," Revista Mexicana de Ciencias Geológicas, Vol. 22, 2005, pp. 383-390.

[36] R. L. Folk, "Petrology of Sedimentary Rocks," University of Texas Publication, Austin, 1968, p. 170.

[37] A. Kar, "Origin and Transformation of Longitudinal Sand Dunes in the Indian Desert," Zeitschrift fur Geomorphologie, Vol. 31, 1987, pp. 311-337.

[38] A. Kar, "Granulometry of Aeolian Bedforms in the Extremely Arid Jaisalmer Region of Thar Desert," In: S. K. Tandon and B. Thakur, Eds., Recent Advances in Geomorphology, Quaternary Geology and Environmental Geosciences: Indian Case Studies, Manisha Publications, New Delhi, 2002, pp. 261-286.

[39] I. V. Buynevich, A. Bitinas and D. Pupienis, "Lithological Anomalies in a Relict Coastal Dune: Geophysical and Paleoenvironmental Markers," Geophysical Research Letters, Vol. 34, 2007, Article ID: L09707. doi:10.1029/2007GL029767

[40] R. K. Borowka, "Problem of the Morphology of Fossil Dune Forms on the £Eba Bar," Quaestiones Geographicae, Vol. 2, 1975, pp. 39-51.

[41] J. Sevink, "Soil Development in the Coastal Dunes and Its Relation to Climate," Landscape Ecology, Vol. 6, No. 1-2, 1991, pp. 49-56. doi:10.1007/BF00157744

[42] K. Pye, "Late Quaternary Development of Coastal Parabolic Megadune Complexes In Northeastern Australia, in Eolian Sediments: Ancient and Modern," In: K. Pye and N. Lancaster, Eds., International Association of Sedimentology, Blackwell Science, Oxford, Special Publishing, Vol. 16, 1993, pp. 23-44.

[43] P. Wilson, J. D. Orford, J. Knight, S. M. Braley and A. G. Wintle, "Late-Holocene (Post-4000 Years BP) Coastal Dune Development in Northumberland, Northeast England," Holocene, Vol. 11, No. 2, 2001, pp. 215-229. doi:10.1191/095968301667179797

[44] R. L. van Dam, S. L. Nichol, P. C. Augustinus, K. E. Parnell, P. L. Hosking and R. F. McLean, "GPR Stratigraphy of a Large Active Dune on Parengarenga Sandspit, New Zealand," Leading Edge, Vol. 22, No. 9, 2003, pp. 865-870. doi:10.1190/1.1614159

[45] K. G. Havholm, D. V. Ames, G. R. Whittecar, B. A. Wenell, S. R. Riggs, H. M. Jol, G. W. Berger and M. A. Holmes, "Stratigraphy of Backbarrier Coastal Dunes, Northern North Carolina and Southern Virginia," Journal of Coastal Research, Vol. 20, No. 4, 2004, pp. 980-999. doi:10.2112/03503A2.1

[46] M. L. Clarke and H. M. Rendell, "Effects of Storminess, Sand Supply and the North Atlantic Oscillation on Sand Invasion and Coastal Dune Accretion in Western Portugal," Holocene, Vol. 16, 2006, pp. 341-355. doi:10.1191/0959683606h1932rp

[47] S. K. Tandon, M. Jain and A. K. Singhvi, "Comparative Development of Mid- to Late Quaternary Fluvial and Fluvio-Aeolian Stratigraphy in the Luni, Sabarmati and Mahi river Basins of Western India," Gondwana Geology Magazine, Vol. 4, 1999, pp. 1-16.

[48] S. K. Tandon, B. K. Sareen, M. S. Rao and A. K. Singhvi, "Aggradation History and Luminescence Chronology of Late Quaternary Semi-Arid Sequences of the Sabarmati Basin, Gujarat," Palaeogeography, Palaeoclimatology, Palaeoecology, Vol. 128, No. 1, 1997, pp. 339-357. doi:10.1016/S0031-0182(96)00035-1

[49] A. Kar, A. K. Singhvi, S. N. Rajaguru, N. Juyal, J. V. Thomas, D. Banerjee and R. P. Dhir, "Reconstruction of Late Quaternary Environment of the Lower Luni Plains, Thar Desert, India," Journal of Quaternary Science, Vol. 16, 2001, pp. 61-68. doi:10.1002/1099-1417(200101)16:1<61::AID-JQS562>3 .0.CO;2-G

[50] N. Juyal, A. Kar, S. N. Rajaguru and A. K. Singhvi, "Luminescence Chronology of Aeolian Deposition during the Late Quaternary on the Southern Margin of Thar Desert, India," Quaternary International, Vol. 104, 2003, pp. 87-98. doi:10.1016/S1040-6182(02)00137-4

[51] J. V. Thomas, A. Kar, A. J. Kailath, N. Juyal, S. N. Rajaguru and A. K. Singhvi, "Late Pleistocene-Holocene History of Aeolian Accumulation in the Thar Desert, India," Zeitschrift fur Geomorphologie Supplement Band, Vol. 116, 1999, pp. 181-194.

[52] T. Naruse, "Aeolian Geomorphology of the Punjab Plains and the North Indian Desert," Annals of Arid Zone, Vol. 24, No. 4, 1985, pp. 267-280.

[53] M. P. Patel and S. J. Desai, "Environmental Significance of Fossil Sand Dunes of North Gujarat," Proceedings of National seminar on Recent Quaternary Studies in India, 1988, pp. 139-147.

[54] Juyal, R. Raj, D. M. Mourya, L. S. Chamyal and A. K. Singhvi, "Chronology of the Late Pleistocene Environment Changes in the Lower Mahi Basin, Western India," Journal of Quaternary Sciences, Vol. 15, No. 5, 2000, pp 501-508.

doi:10.1002/1099-1417(200007)15:5<501::AID-JQS528> 3.0.CO;2-J

[55] S. A. Wolfe, D. R. Muhs, P. P. David and J. P. McGeehin, "Chronology and Geochemistry of Late Holocene Eolian Deposits in the Brandon Sand Hills, Manitoba, Canada," Quaternary International, Vol. 67, 2000, pp. 61-74. doi:10.1016/S1040-6182(00)00009-4 